\title{
SOME EFFECTS OF THE SECURITIES ACT UPON INVESTMENT BANKING
}

\author{
Wirliam O. Douglas* and GeORGe E. Bates $\dagger$
}

$A_{\text {-make prediction of the effects of the Securities Act of } 1933^{1} \text { as }}^{\text {HOST of imponderable factors-political, psychological, economic }}$ respects any group or groups hazardous. Especially is this true of the institutions or individuals commonly identified as investment bankers. It is equally difficult to predict effects of the Act upon the performance of investment banking functions particularly without full recognition of the effects of the Act upon issuers, their officers and experts, and upon the forms and types of securities issued. ${ }^{2}$ Nevertheless at the risk of the artificiality of an abstraction which gives but slight recognition to those various factors, it is the purpose of this essay to single out for discussion the effects of the Act bearing directly upon the performance of investment banking functions. Of necessity the conclusions must be general, and descriptive merely of possible or probable trends. Furthermore they will be restricted largely to a description of the impact of the Act-in terms of increased or lessened business or legal risks-on the performance of the functions of investment banking.

Those functions are scarcely differentiated by the Act. ${ }^{3}$ It makes no dis-

* Professor, Yale University School of Law.

† Assistant Professor, Harvard Graduate School of Business Administration; Research Associate, Yale University School of Law.

× 73 d Congress, H. R. 5480, Title I, approved by the President May 27, I933, hereinafter cited as the "Act."

${ }^{2}$ In a forthcoming issue of the Yale Law Journal the authors expect to set forth those other effects of the Act and relate them to investment banking as they affect the volume and character of issues offered. For the constitutionality of the Act, assumed and not discussed in this essay, reference is made to an article by Professor Nathan Isaacs in the same issue of the Yale Law Journal.

${ }^{3}$ As commonly defined, investment banking comprises the gathering of a multitude of small savings for bulk long-term investment in political units, industry, trade, commodities, and real estate. As such it may be variously, and often jointly, performed by the issuers of the securities involved, some intermediate issuers such as political bodies or investment companies, such institutions as insurance companies, savings banks, and even commercial banks, and specialists in the granting and underwriting of long-term credits and the distribution of securities to investors and investing institutions.

These specialists are known as investment bankers, though sometimes the term is confined to a small number of them who originate or are the principal underwriters for the majority of security issues (also variously described as "originators," "underwriters" and "houses of issue"), and at times is extended to include every small retailer. (Even the door-to-door peddler of highly speculative promotional stock or of purely fake securities has seen fit to appropriate the title.)

Not comprehended in the foregoing definition are some transactions, such as those effecting 
tinction in terms between originating houses and other underwriters, nor between principal underwriters and sub-underwriters. ${ }^{4}$ Accordingly a realistic conception of the processes involved is essential in order to understand this significant experiment in social control over finance.

\section{ORIGINATING}

As distinguished from the technical underwriting of an issue, some investment banker, herein referred to as the "originator," must approach, be approached by, promote, or control, the prospective issuer of securities. Before deciding upon the desirability of buying, underwriting the sale of, or distributing those securities he must make, or cause experts to make, an investigation of the enterprise, the securities proposed to be issued, and the market in which they will be offered..$^{5}$ If the credit or capital investment appears warranted and practicable, he may then advise the prospective issuer as to the type and form of security which will best meet its requirements and those of the market. Here typically begin negotiations, sometimes protracted, over the sum to be raised, the precise nature of the security, the inclusion of protective provisions, the kind of issue, the price, and the gross spread.

In the performance of the foregoing function the originator does not become an "underwriter" under the Act. ${ }^{6}$ If, in the event of "underwriting" then being assumed by others, he should divorce himself from the undertaking, he would incur no risks under the Act, except those that might follow upon the use of his name, as giving authority to any statements made in the registration statement, ${ }^{7}$ or from his possible control over the

the transfer of a block of outstanding securities from one group of investors to another, which are usually considered to be investment banking when involving general distribution (and normally investigation, negotiation, and underwriting).

Much popular confusion in terminology (and consequently in analysis) has resulted from the performance by these investment bankers of many non-investment banking functions, such as brokerage and commercial banking, and from the incidental performance by brokers, commercial bankers, investment counselors, and others of investment banking functions.

${ }^{4}$ Both security merchants and brokers are defined as "dealers" in \$2(12). Some merchants and brokers are classed as "underwriters" in $\$ 2(\mathrm{Ir})$, which provides no classification of underwriting. $\S_{4}(\mathrm{I})$ and $(2)$ implies some further distinction, but is not clear.

5 Even the seemingly voluminous requirements for the registration statement under Schedules $A$ and $B$ would comprise but a portion of the facts usually necessary for the formation of the banker's judgment.

${ }^{6}$ Since under $\$ 2(\mathrm{Ir})$ he has not purchased from or sold for an issuer. If he subsequently becomes an "underwriter" under $\S 2$ (II), these "preliminary negotiations or agreements" are specifically excluded under $\$ 2(3)$. Query, if he later takes no commitment might he not be an underwriter because of his "participation"?

$$
7 \S \text { II (a) (4) and (b) (3) (B) (I) and (II). }
$$


issuer, its officers or experts. ${ }^{8}$ In contrast to the Companies Act, his possible connection with the issuer as a promoter involves no additional risk. ${ }^{9}$

In practice, however, the originator has normally contemplated participation in the underwriting. It has been one of his further functions to organize, manage, and represent the underwriters and distributors in dealing with the issue. At that point he would become an "underwriter" under the Act. His obligations, not being differentiated from those of other "underwriters" by the Act, will be discussed in the following section.

Inasmuch as the originator is the most prominent of the investment banking houses identified with the issue and is in direct contact with the issuer, upon it usually has rested responsibility for keeping watch over the issue and the affairs of the issuer and, in the event of difficulty, impending or actual, to represent the interests of the holders of the security it has originated. ${ }^{\text {10 }}$ The Act imposes new deterrents to a part of this rôle of the

$8 \S \mathrm{I} 5$ and, as to representation in management, $\S \mathrm{II}(\mathrm{a})(2)$. The representation of investment bankers upon the boards of directors of issuers has been fairly common. It has been looked upon by many as affording some measure of protection to security holders; others have taken it as evidence of banker control of industry and as a means of business promotion for investment bankers and of affording some insurance for them against future issues going to competitors.

'I 9 and 20 Geo. 5, c. 23. Under $\S 37$ which imposes liability for "any untrue statement" in the prospectus "every person being a promoter of the company" and "every person who has authorized the issue of the prospectus" are among those held liable to subscribers. The term promoter is defined in $\S 37(4)$ as meaning "a promoter who was a party to the preparation of the prospectus, or of the portion thereof containing the untrue statement, but does not include any person by reason of his acting in a professional capacity for persons engaged in procuring the formation of the company." Originators therefore would not necessarily be liable under the Companies Act unless they had become parties to the preparation of the prospectus or of that portion sued upon. Such participation under our Act without more would not impose any liability by virtue of the Act. Yet as Berle points out "Though not defnitely stated, the "promoter' is also in the picture but he is left to be determined by the ordinary processes of the common law, and litigation may be expected on this point." Berle, New Protection for Buyers of Securities, N.Y. Times, June 4, I933, $\$ 8$, p.x.

The point of departure between our Act and the English Act on this point seems clear. The latter is designed to hold responsible those who in light of their investigation (or perhaps regardless of it) proceed to prepare for the public misleading and inaccurate prospectuses. Our Act, however, is not primarily concerned with the person who made the investigation, who was in a position to verify the statements, and who aided or abetted the issuer of the prospectus in advertising inaccurate or misleading statements. It is only when that person steps into the rôle of underwriter that the Act regulates him. This may or may not be an improvement over the English procedure. The possible difficulties resulting from separating liability from the investigatory functions of the investment banker will appear more clearly in the subsequent discussion in the text.

so Doubtless cases exist in which investment bankers have performed this function more with a view to further profit than to the protection of security holders, and such instances or the allegation of such motivation has led to much criticism. Were originating houses to refrain from the performance of that function, however, criticism probably would be aroused and their issues suffer disrepute. 
originator, since as an "underwriter" he is made subject to liabilities discussed in the following section. ${ }^{\text {Ir }}$

The result is that as originator the banker assumes but few new legal risks under the Act in his promotional or strict originating rôle. It is underwriting, not investigation or promotion, that is material under the Act.

\section{UNDERWRITING}

Great variety in procedure has been characteristic of "underwriting" in this country. This flexibility has permitted the evolution of methods adapted to continually changing conditions. The variety and complexity of method, however, and the shifting application of the word "underwriting" have not promoted popular understanding. To an extent strict underwriting (i.e., an agreement by one party to compensate another to the extent of the latter's failure to obtain purchasers for an issue, or to take from the latter such unsold portion of the issue at a price) ${ }^{12}$ has continued in existence along with, and frequently in conjunction with, outright purchase (or agreements to find purchasers) of issues. Both such purchases and true underwriting have been denominated "underwriting." Further complication has resulted from the employment of this "underwriting" device as a means of wholesale distribution for securities.

Perhaps an example will clarify what is meant by these various types of underwriting:

I. To refund a maturing note a prospective issuer of additional common stock plans an offering for cash to existing stockholders, because of their preëmptive rights. In order to obtain an amount certain to meet the maturity, $i t$ desires to "insure" the sale to stockholders. An originating banker is approached, who upon investigating decides that he will underwrite the sale for a commission (analogous to an insurance "premium") of $\mathrm{I} \%$ of the entire issue plus an additional $4 \%$ of the amount unsubscribed by stockholders and required to be taken up by the underwriter. ${ }^{23}$ Inasmuch as the amount involved is large and his capital insufficient for conservatively carrying the risk alone, the banker either agrees to form, or forms, an underwriting group to take this commitment; or he may take the commitment alone but almost immediately transfer it ("re-insure" in the insurance analogy) to a group of underwriters of which

${ }^{x r}$ See discussion infra, p. 286.

rz In re Licensed Victuallers' Mutual Trading Ass'n., L.R. 42 Ch. D. I (I889) defines underwriting (in what might be called its technical or strict legal sense) as "an agreement entered into before the shares are brought before the public, that in the event of the public not taking up the whole of them, or the number mentioned in the agreement, the underwriter will, for an agreed commission, take an allotment of such part of the shares as the public has not applied for."

${ }^{13}$ The hypothetical commissions used would seem to indicate that although this banker seemed doubtful of the success of the offering to stockholders he judged that the underwriters would be able to dispose of it without too great difficulty. 
he will probably be a member. This is a type of what has been described as strict underwriting.

2. If stockholders subscribe for the entire issue, the underwriters receive their $\mathrm{I} \%$ commission as a gross profit from which they would deduct their expenses and out of which strict accounting would require their establishing reserves adequate to meet losses on unsuccessful underwritings (if the risks were predictable on an actuarial basis). Assume, however, that the stockholders subscribed for only $20 \%$ of the issue. Then the underwriters would receive their $\mathrm{I} \%$ commission on that $20 \%$, while they would be required to take up the remaining $80 \%$ of the stock from the issuer at the offering price to the stockholders less $5 \%$. The net result would be to leave them $5^{1 \%} \%$, less expenses, on which to distribute the stock acquired if sold at the price at which it had been offered to stockholders. To simplify the illustration let it be assumed that the offering price (say, of \$roo per share) had coincided with the market, so that the subscription privilege ("rights") given stockholders was valueless, and that the market had not varied during the subscription period. The underwriters then might decide to market the issue at or slightly below the same price. ${ }^{44}$

Because the failure of stockholders to take more of the issue showed the risk to be greater than perhaps originally estimated, and because the underwriters probably would desire assurance of promptly disposing of the stock in order to free their capital for other underwriting, they might then form another and perhaps larger underwriting group to guarantee their sale of the issue. This group might be asked to buy so much of the stock from the original group as would reduce its commitment the desired amount, but since it would be more advantageous to have a single group under one management, the members of the original group would probably become members of the second and larger group, which would acquire the entire issue. (The transfer from the first to the second group might be at $\$ 95$ per share, giving the former $25 \mathrm{C}$ for expenses, profit, and the risk incurred, and the latter $\$ 5$ on which to cover risks, expenses of distribution, and profit.) This type of purchase rather than strict underwriting or guarantee of sale has been commonly used, and has been commonly called "underwriting." To avoid an unnecessary number of transfers, upon which transfer taxes would accrue, however, it is probable that the commitment of the second group in this example would take the form of a strict underwriting. (In that event, the commission to the second group might be $50 \mathrm{c}$ per share with a contingent take-up price of $\$ 95.50$ per share.)

3. Since this group was only made large enough to assure adequate spread of the risk, but not so large as to cause uncertainty or delay in accomplishing this purpose, its members might either lack or have insufficient retailing capacity to distribute all the stock. A much larger group would then be formed for the purpose of wholesaling the issue. (Or two or more groups might be formed with a view to giving certain retailers, through membership in more than one group, greater compensation, either as reward in the nature of a special quantity discount for taking larger allotments of stock to retail, or for other past or prospective services.) For this purpose a so-called selling syndicate might be used in which all members agreed to underwrite a certain proportion

${ }^{14}$ In most cases the stockholders' failure to subscribe would be the result of a fall in the market which made the privilege valueless, with the result that underwriters would either have to carry the stock speculatively against a rise in the market or sell it at a lower price which would either materially reduce or more than wipe out their margin. 
of the whole but might actually retail a greater or lesser amount or none. An alternative would be to use a selling group whose members were not called upon technically to underwrite but to purchase the stock at wholesale (that is, at the retail price less a selling commission). Insofar as retailers actually subscribed for stock in the selling group the risk would be as effectively transferred as in an underwriting syndicate. If all selling group members purchased stock in this way for resale the transference of risk from the underwriting group (except those risks possibly incurred through a trading account) would be as effective as in an underwriting (especially if the latter sort were of limited liability and did not involve a trading account). Under many circumstances, however, retail dealers would subscribe only as they received orders from customers. In a sense they might appear then to be acting merely as brokers. ${ }^{15}$ In many cases they would not acquire title to the stock, but it would pass directly to the investor. ${ }^{16}$

While the foregoing example over-simplifies the problem of underwriting, it will suffice for the purpose of examining some possible effects of the Act on such practices.

The result may or may not be a radical change in this procedure. Prophecy is difficult. Yet it may well be that the effect of the Act will be in the direction of retarding the affliation of substantial houses in such undertakings. These are the reasons. In the first place, the word "sell" as defined in $\$ 2(3)$ expressly excludes "preliminary negotiations or agreements between an issuer and any underwriter." But negotiations or agreements between the originating house and other houses which are approached by the originating house for participation in the underwriting are not excluded. Hence offering such participation to other houses would be an "offer to sell" or "attempt or offer to dispose of" a security or an "interest in a security." Under $\S 2(3)$ the risks of the originating house in so selling or offering to sell might be considerable in case any means or instruments of transportation or communication in interstate commerce or the mails were employed. ${ }^{17}$ Unless a registration statement were in effect $\S 5$ would be violated. Its wilful violation may entail either a $\$ 5000$

xs Cf. Bates \& Douglas, Secondary Distribution of Securities-Problems Suggested by Kinney v. Glenny, 4I Yale L. Jour. 949-x004 (r932).

${ }^{16}$ See article by the authors in Yale L. Jour., Nov. r933, entitled Stock "Brokers" as Agents and Dealers.

x7 It should be noted, however, that civil liability under $\$$ I2 would probably follow even though only part of the entire transaction was consummated in interstate commerce or through the mails. Thus solicitation of the sale through the mails or by interstate commerce followed by delivery of the security in a wholly intrastate transaction without use of the mails would probably suffice, and vice versa. $\$ 2(7)$ defines "interstate commerce" as meaning "trade or commerce in securities or any transportation or communication relating thereto" etc. See Dean, The Federal Securities Act: I, 8 Fortune 50 (1933). A similar observation can be made under $\S$ II with the following qualification. See Reg. No. 85, H. R. 73d Cong. Ist Sess. p. 22. A person is entitled to rely on the registration (and need not prove he relied on it) even though his particular transaction was an intrastate sale not involving the use of the mails. $\$ 5$ (c), however, exempts "the sale of any security where the issue of which it is a part is sold only to 
fine or five years in prison or both. ${ }^{18}$ Furthermore, any of the houses taking participation from the originating house could sue the latter for damages or for rescission ${ }^{\mathrm{x}}$ any time within two years thereafter..$^{20}$ And the action for damages need show no causal relationship whatsoever between anything the originating house said or did and what subsequently happened to the security. ${ }^{2 x}$

Yet even if a registration statement is in effect, or even though the security is not required to be registered, the originating house takes the risk [except as to securities exempt under 3 (a) (2)] ${ }^{22}$ of a suit for damages or rescission by the participating houses if agencies of interstate commerce or the mails have been used in the communication and the latter includes an untrue statement of a material fact or omits to state a material fact necessary to make the statements in light of the circumstances under which they were made not misleading. ${ }^{23}$

The result desired (viz., a wider distribution of the underwriting risk) may be partially effected by bringing into the preliminary negotiations with the issuer all of the houses who are going to participate directly or indirectly in the underwriting, or by having the issuer itself make up the banking and purchase syndicates through direct negotiations with them. The former is impracticable to any great extent. ${ }^{24}$ The latter entails the

persons resident within a single State or Territory, where the issuer of such securities is a person resident and doing business within, or, if a corporation, incorporated by and doing business within, such State or Territory."

${ }^{18} \S 24$. Possible liability under $\S$ I 7 should also be noted. That section merely makes it "unlawful for any person in the sale of any securities" by the use of interstate agencies or of the mails, inter alia, "to obtain money or property by means of any untrue statement of a materia] fact or any omission to state a material fact necessary in order to make the statements made, in the light of the circumstances under which they were made, not misleading." None of the securities otherwise exempted from the Act are exempted from the operation of this section. The nature or extent of liability is not stated in $\S$ I7. The use of the word "unlawful" coupled with the fact that $\$ \S$ I I and I 2 specify the civil liabilities under the Act leads to the inference that $\$ I 7$ is criminal not civil. If so, the penalties would be exacted under $\$ 24$ only for wilful violations. If, however, the section imposes civil liability, it goes far beyond even $\$$ I2(2) which after all exempts certain securities, gives defenses of the exercise of reasonable care and of the knowledge of the purchaser of the untruth or omission, and limits recovery to the person "purchasing such security from him." Possible ambiguity in $\S$ I 7 should be clarified by amendment.

$29 \& \mathrm{I} 2(\mathrm{x})$.

${ }^{2} \&$ r3. Due to lack of clarity the period might be interpreted as ten years.

${ }^{21}$ This would not necessarily follow in a suit under $\$ \mathrm{r} 2(2)$. But the purchaser to make out a case under $\S \mathrm{I2}(\mathrm{I})$ need only show a violation of $\S 5$.

$22 \S 12(2)$.

${ }^{23} \mathrm{Id}$. See also supra, note 17 .

${ }^{24}$ Conceivably the issuer might approach a small group of banking houses the members of which could severally investigate the financing. [The Act provides no guide, however, as to 
risk that the issuer acting under the supervision and direction of the originating house might be held to be the agent of the originating house. In such event the originator would run afoul of $\S \S 5$ and I 2 in the same way as if it had not acted through the instrumentality of another.

These difficulties insofar as they involve increased risks of liability of the originating house to participating houses may be partially discounted by the fact that members of the banking fraternity would be less likely to attempt to renig against one of the fraternity than would outsiders. Yet no matter how these risks are discounted even larger ones remain. By definition in $\$ 2$ (II) every member of a banking syndicate, every member of a purchase syndicate, every member of a selling syndicate, and conceivably every member of a selling group ${ }^{25}$ becomes an underwriter. The security (not being exempt) is registered. If the registration statement contained "an untrue statement of a material fact or omitted to state a material fact required to be stated therein or necessary to make the statements therein not misleading," any person acquiring the security (unless it were proved that at the time he acquired the security he knew of such untruth or omission) could sue "every underwriter" for damages or for rescission. ${ }^{26}$ To this there are several exceptions, the two most relevant here being the following: (I) If that part of the registration statement was made on the authority of an expert (other than himself) he is not liable if he had reasonable ground for belief and did believe that the statements were true and that there was no omission to state a material fact; $; 7$ (2) In case the error or omission was in a part of the registration statement not purporting to be made on the authority of an expert nor to be taken from his report or from some public document, then to escape liability he must prove that he had "after reasonable investigation, reasonable ground to believe and did believe" that the statement was accurate. ${ }^{28}$

how far they could cooperate to avoid duplication of effort and expense and to reach agreement by negotiation as to the kind and provisions of the security and the conditions of its offering without running foul of $\S 5$ under the definition of "sell" in $\S 2(3)$ ]. If the issuer was at a distance from a financial center or were relatively unknown, the difficulties and expense of such a course would obviously be multiplied. For issues of such size as to require a considerable spread of the risk to achieve real underwriting, the impracticability is apparent of an issuer attempting to approach a hundred or more prospective underwriters (scattered from Boston to Los Angeles and from Minneapolis to New Orleans), each of whom would be required to make such an investigation as would be proper to a fiduciary, and among whom agreement could scarcely be expected as to the forms of contracts and "indentures," the price and spread, and similar considerations (unless the issuer were constantly in the capital market and, so, thoroughly conversant with its current demands).

${ }_{25}$ In case, for example, the selling group agreement required members to repurchase securities coming back upon the market during a specified period.
${ }^{26} \S$ II (a) 5 .
$27 \S$ II (b) (3) (C).
${ }^{28} \S \operatorname{Ir}(\mathrm{b})(3)(\mathrm{A})$. 
And the standard of reasonableness imposed is "that required of a person occupying a fiduciary relationship." 29

A house offered participation in a banking or purchase syndicate usually will not have the benefit of reliance on an expert for every statement in the registration statement. Probably the bulk of the statement will be comprised of facts which it must reasonably believe to be true after its own reasonable investigation. And in making its investigation it must remember that it is a fiduciary. As a practical matter it cannot duplicate the study which the originating house made. Nor can it even go so far as to examine all the data which the originating house has collected. Not only would time and expense be prohibitive but frequently it would have no facilities for making the investigation. It has arrived at a point where it must take a chance. That chance would be that the originating house had made a thorough check and that it and the issuer had prepared a registration statement that would stand up under the critical eyes of $\S$ II and juries throughout the land..$^{30}$ It could hardly be said to have made a reasonable investigation if it merely accepted the originator's word. ${ }^{3 \mathrm{x}}$ The risk it would assume would not be measured by the contract it had made with the originating house. Regardless of its commitment thereunder it would be responsible to investors for the whole issue. Under $\S$ II the liability in rescission would be the consideration paid for the security. ${ }^{32}$ If,

$29 \S \mathrm{Ir}(\mathrm{c})$. Criticism of the Act is frequently heard on the grounds that this standard is too high and that the chances of liability in hard cases is great, especially at the hands of juries. This point will be developed in the forthcoming article in the Yale Law Journal. A rather wide sample of cases indicates in general that the rule is fairly uniform and not unreasonably severe. It is stated in the Restatement of the Law of Trusts, Tent. Draft No. 2, $\S 169$ as follows: "The trustee is under a duty to the beneficiary in administering the trust to exercise such care and skill as a man of ordinary prudence would exercise in dealing with his own property; and if the trustee has greater skill than that of a man of ordinary prudence, he is under a duty to exercise such skill as he has."

$3^{\circ}$ It should be noted that $\S 22$ (a) gives State and Territorial courts jurisdiction concurrent with federal district courts in all suits in equity and actions at law brought to enforce any liability or duty created by the Act. The desirability of restricting jurisdiction to the Federal courts will be discussed in the forthcoming article in the Yale Law Journal.

${ }^{3 x}$ It would seem doubtful that the entire registration statement would purport to be made on the authority of the originator as an "expert." Acceptance of the originator's word where the originator admittedly was a banking house of great character, repute, and reliability could hardly pass as a substitute for this underwriter's own "reasonable investigation." Cf. Adams v. Thrift, [1915] 2 Ch. 22. Under the English Companies Act \$ 37, however, the defenses available to persons liable, e.g. directors, include "reasonable ground to believe" that the statement in the prospectus was true. Hence the English cases are not particularly relevant in determining the meaning of "reasonable investigation" under $\$$ II of the Act.

${ }^{32}$ With interest, less amount of income received. $\$$ II (e). And in no event would the plaintiff be entitled to recover more than the price at which the security was "offered to the public." $\S \mathrm{II}(\mathrm{g})$. 
however, plaintiff has sold the security, he is entitled to damages in an amount limited to the price at which the security was offered to the public. ${ }^{33}$ Among the various ambiguities and uncertainties in the section only two need be mentioned here. A strict reading of $\S$ II eliminates all elements of causation. The untrue statements or the omissions apparently need have no causal relation either to the investment or to the damages. ${ }^{34}$ And while a particular plaintiff may recover an amount not in excess of the price at which the security was offered to the public, the aggregate amount so recoverable is not thus limited expressly. Theoretically, therefore, suits for damages by successive purchasers of the security might cause the damages to mount way above the amount of the issue or the total offering price. An attempt to resolve these provisions of $\S$ II into a workable and congruous whole will not be attempted here. It is believed, however, that even without amendment the section would be interpreted not literally but with common sense by the courts. ${ }^{35}$ Yet its perplexity and uncertainty add but one more factor to the pyschological (if not legal) hazard confronting "underwriters" (and their counsel). The result of the combination of these uncertainties may be a tendency to reduce the number of . banking houses participating as "underwriters" of issues. ${ }^{36}$ For only those who can act substantially as originators would seem to be able to satisfy the tests of reasonable investigation set down in $\S I^{37}$ and therefore able to avoid running the gauntlet of diverse court rulings on the ambiguities and uncertainties in the damage clauses of that section.

${ }^{33} \S \mathrm{Ir}(\mathrm{e})$ and $(\mathrm{g})$.

34 For comparison with some of the companies acts in England see Cackett v. Keswick, 85 L. T. Rep. I4, I6 (Igor); In re Wimbledon Olympia Ltd., [I9ro] I Ch. 630, 632.

${ }^{35}$ See in this connection the interpretation given by Baldwin B. Bane, Chief of Securities Division, Federal Trade Commission, released Sept. 22, I933 and published in the N.Y. Times, p. 21, Sept. 23, I933.

${ }^{36} \mathrm{It}$ is assumed throughout that underwriters (in a business sense rather than that of the Act) are those actually able to finance their proportionate share of an underwriting, not merely those willing to have issuers gamble on their ability to sell some portion or the whole of an issue (even though these latter frequently refer to themselves as underwriters).

37 It might be possible for originators or principal underwriters to protect sub-underwriters by having every detail in the registration statement vouched for by recognized authorities (if such could be found, other than strawmen whose lack of substance or independence might raise question as to their reliability, who would assume joint and several liability for the whole issue) upon whose statements courts might hold sub-underwriters and dealers justified in relying as fiduciaries.

It is true that the person held liable might have an action of contribution against others under $\S \mathrm{II}(\mathrm{f})$. Full analysis of that section is not possible here. The action would be "as in cases of contract" and would lie against "any person, who, if sued separately, would have been liable to make the same payment, unless the person who has become liable was, and the other was not, guilty of fraudulent misrepresentations." 
The provisions in $\S 8$ that the effective date of a registration statement shall be the twentieth day after filing ${ }^{38}$ and that the Federal Trade Commission has the power to issue stop orders in case of untrue or misleading registration statements ${ }^{39}$ will certainly affect the form if not the substance of underwriting agreements. These provisions have been thought by some to mean the end of any commitments by bankers to underwrite the issue for the company. It probably would be more accurate to predict that in underwriting agreements in the future there will appear many new hedge clauses conditioning the firm commitments of bankers, since the issuance of a stop order would be disastrous to any plans for marketing in the near future. Furthermore since market prices and conditions are by no means static and might vary considerably during the waiting period, clauses covering the adjustment of price and consequently the "spread" of the bankers will probably appear. It may be $4^{0}$ that amendments to the registration statement will have to be filed in order to state the new offering price and any accompanying adjustment to the bankers' "spread," although in some cases adequate formulae can probably be worked out making this unnecessary.

But, since, as discussed above, negotiations between the originating house and other prospective underwriters cannot safely proceed ${ }^{4 \mathrm{I}}$ unless the security is registered, it is to be expected that amendments covering the details of underwriting will be filed after the expiration of the twenty day period. Their effective date is determinable by the Commission. ${ }^{42}$ Thus the actual waiting period may be much longer than twenty days. The uncertainty of getting any underwriting will therefore continue until after the twenty day period. That may well result in the additional hedge clause qualifying or conditioning the commitment of the originator to the issuer on the success of the subsequent attempts to obtain underwriting.

These changes in procedure, disastrous as they may seem to some, are probably merely matters of detail as compared with the fundamental change which the Act makes as respects the responsibility of underwriters. This latter feature when taken in conjunction with the changing forms of
${ }^{38} \& 8(a)$.
${ }^{39} \$ 8$ (d) (e) and (f).

40 Schedule $A(16)$ provides that "A variation in price may be proposed prior to the date of the public offering of the security, but the Commission shall immediately be notified of such variation." Such notification conceivably need not be in form of an amendment to the registration statement. But it is not clear. Until the Commission has ruled otherwise it would obviously be the course of prudence to amend pursuant to $\$ 8$.

${ }^{4 x}$ Note that such transactions are specifically exempted from certain provisions of the English Companies Act. See $\S 35(3)$.

${ }^{42}$ " . . . . having due regard to the public interest and the protection of investors." $\$ 8(c)$. 
procedure may have great significance primarily as respects the issuer, secondarily as respects the investors.

In passing, one other problem raised in connection with the definition of "underwriter" in the Act should be noted. When read carefully it includes all those who are commonly known as underwriters except perhaps the strict underwriter. An underwriter is not necessarily one who "has purchased from an issuer with a view to, or sells for an issuer in connection with, the distribution of any security" nor anyone who participates directly or indirectly in "such undertaking" or participates in the direct or indirect "underwriting" (obviously used in the sense in which it is defined) of "such undertaking." The strict underwriter who merely agrees to take the securities at a price if the issuer cannot sell them may or may not purchase them "with a view to" distribution. Distribution at that time would usually be out of the question. He may take them with a view to management of the company or to a long-term holding. So on the facts of some cases we might have underwriters immune from any liability under the act. ${ }^{43}$ If the practice as regards underwriting continues as it has in the past in this country, however, there usually would be at least one banking house as regards a particular issue falling within the definition of "underwriter" in the Act, for as noted above the practice has been for the banking group contracting with the company to perform a distribution function. Any other bankers participating directly or indirectly in such an undertaking or in the underwriting of such an undertaking would therefore be underwriters under the Act.

Reference has been made above to the increased liability under the Act of investment bankers (as "underwriters") who seek to protect securities

43 Before the enactment of prohibitory legislation the life insurance companies were in a position to, and did, perform strict underwriting. The necessity for greater marketability in the investment portfolios of other insurance companies and banks probably preclude their participation, but investment trusts might find this a desirable business.

Even if such strict underwriting were available, however, two factors would probably make it impracticable. Few such underwriters would be in a position to perform that function continuously without turning over their capital and if such a turnover were implicit in the business it might readily be held that their commitments were with a "view to distribution." Secondly, a "view to distribution" is no more than a motive and there would be no way in which any underwriter could be certain that some other underwriter might not subsequently be held to have had such a motive, so that his "participation in any such undertaking" might make him also an "underwriter" under $\$ 2$ (rr).

Under date of Sept. 22, I933 the Federal Trade Commission ruled as follows on one meaning of distribution in $\S 2(\mathrm{rI})$ : "A person, the chief part of the business of which consists in the purchase of the securities of any one issuer, its subsidiary and/or affiliate and in the sale of its own securities to furnish the proceeds with which to acquire the securities of such issuer, subsidiary and/or affiliate, is to be regarded as engaged in the distribution of the securities of such issuer, subsidiary and/or affiliate within the meaning of Section 2(Ir)." 
which they have originated. Thus in case a company was in the process of voluntary reorganization or a refunding program was desired, it has been rather common for investment bankers to occupy prominent places on committees organized to facilitate the exchange of securities. Under the Act the investment banker acting as "depositor" or manager of such a committee is subject to new liabilities. As "depositor" or manager where certificates of deposit are issued for securities of the company he would be liable as an issuer ${ }^{44}$ under the Act and liable pursuant to $\$$ I I for the certificates of deposit. And even though he is not such an issuer, $\S$ I 5 would impose the liability of an issuer on him if by formal or informal arrangement he "controls" the issuer of the certificates of deposit. And even though the committee of which he is "depositor" or manager, or the committee which he controls, is accepting deposits of securities of a company in bankruptcy or receivership, such liability might be imposed. In the first place such securities to be exempt under $\$ 4(3)$ must be of a corporation "in the process of a bona fide reorganization" under the "supervision of any court." Committees, however, frequently are formed too early to determine with finality whether or not there will be a reorganization or liquidation and often before it can be said that the court is supervising ${ }^{45} \mathrm{a}$ "bona fide reorganization." The risks of action within the interim period are obvious. In the second place $\S 4(3)$ probably intends to give exemption solely to exchanges between a corporation and its security holders and not between a committee and security holders. ${ }^{46}$ If that is true, there need be a registration statement covering the certificates of deposit. On that the "depositor" or manager would appear as issuer.

Or, again, the banker may be a member of a committee to induce the exchange of securities directly with the company or through the agency of a depository or other fiscal agent. To be sure $\$ 4(3)$ exempts the issuance of a security of a "person exchanged by it" with its existing security

$44 \$ 2(4)$ defines "issuer" to mean "with respect to certificates of deposit" the "person or persons performing the acts and assuming the duties of depositor or manager pursuant to the provisions of the .... instrument under which such securities are issued." Under $\S 4(\mathrm{I})$ the committee might possibly be exempt from necessity to register the certificates since the transaction was "not with or through an underwriter" and did not involve "any public offering." It is by no means clear, however, that such solicitation could not amount to a public offering.

${ }^{45}$ Cf. Lowenthal, The Investor Pays (r933).

${ }_{4}^{6}$ The section is ambiguous. The previous clause (dealing with an exchange of securities with existing security holders) is limited to the issuance by the company ("exchanged by it"). The subsequent clause dealing with judicial reorganization does not qualify "issuance of securities." So it is at least arguable that certificates of deposit are included in the exemption. It seems, however, that the implications of the section are to restrict the exemption to issuance by a corporation which is in such process of reorganization. 
holders "exclusively" provided "no commission or other remuneration is paid or given directly or indirectly" in connection with the exchange. So that if the depository was receiving no fee or commission and if no other party (such as fiscal agents, transfer agents, or others) was receiving any remuneration, the exchange would be an exempt transaction. But it would be the exception rather than the rule to find no one receiving remuneration. Hence it would seem necessary to register the "security." 47

If the section means what it says, some impetus may be given to receivership or bankruptcy proceedings because of the hazards involved in voluntary readjustment and refunding programs. This tendency will be accentuated if "commission or other remuneration" in $\S_{4}(3)$ is not restricted to commissions for soliciting exchanges.

There are, moreover, other problems raised by $\S 2$ (II) which should be resolved by clarifying amendments. An issuer who elects or is forced to perform its own distribution under the Act may find its hands tied. If it operates through brokers and dealers giving them only the regular or customary brokers' or dealers' commission, nevertheless the brokers and dealers might well become "underwriters" under the Act and therefore liable for the whole issue. As previously pointed out the word "sell" is broadly used in the Act and not restricted to its narrow legal sense. It would embrace the activities either of a broker or dealer in distributing a security for an issuer on a commision basis. Therefore either a broker or dealer would be liable as "underwriter" unless he were protected by other provisions of the Act. Section 2(II) exempts from the definition of "underwriter" a person whose interest is limited to a commission from an underwriter or dealer not in excess of the usual and customary distributors' or sellers' commission. Therefore dealers or brokers who distribute in such fashion for underwriters would not be underwriters under the Act. But dealers or brokers ${ }^{8}$ who distribute for issuers would be. The result is that the issuer who desired to do its own distributing through broker

47 Difficulty in obtaining a registration might be expected in case of foreign issues presently outstanding. Query, if the banker, as member of a committee or otherwise solicits or seeks to induce the exchange of securities might he not be held as an underwriter? "Sell" as defined includes "attempt or offer to dispose of." Therefore might he be held to be selling "for an issuer in connection with the distribution of any security"? If so, no matter if he acts gratuitously and does not himself accept or exchange securities, he may be acting as underwriter and be liable civilly under $\S$ I I as well as criminally under $\$ \S I 7$ and 24 . It could be agreed that while in no strict sense an "agent" of the company in soliciting the exchange, nevertheless in a realistic sense he was acting for its benefit and with its general advice and approval. The consensual arrangement between them might result in him being held to have sold "for the issuer." Possibly, though not probably, investment counsel or financial writers might similarly creep in as underwriters.

$4^{8} \S 4(2)$. 
and dealer channels might find brokers and dealers throughout the land unwilling to assume responsibility for the whole issue. An obvious dodge would be for the issuer to make a strawman an "underwriter" and then proceed to have him contract with brokers and dealers who thereby would not become "underwriters." 49 But it seems unfortunate to have tu resort to such a palpable dodge in order to carry out the intent and design of the Act.

The liabilities of brokers and dealers in retailing securities will be discussed hereafter. In passing, however, it should be noted that there are still further chances for a dealer to be held liable as an underwriter under the Act. By express provision \$2(II) exempts from classification as "underwriter" a person whose "interest is limited to a commission from an underwriter or dealer not in excess of the usual and customary distributors' or sellers' commission." Would a member of a selling syndicate described above be liable? That depends on the construction of "usual and customary distributors' or sellers' commission." The phrase needs clarification. It is doubtful if "distributors" " is used synonymously with "underwriters." "If so, the exception would swallow most of the rule. Accordingly it would seem that the exception meant to exempt purchases at wholesale (that is at retail price less a selling commission) and salesmen's commissions from dealers. If that is the meaning, the line of cleavage in the section is not between wholesaling and retailing, but between ordinary retail (and perhaps wholesale) commissions, on the one hand, and, on the other, compensation (or possibility of compensation) for some service whose performance it was thought might tend to increase the incentive and pressure for quick and permanent placement of securities with the public. Since subscriptions by selling group members in advance of customer orders (discussed in the following section) would produce essentially the same incentives as participation in many sorts of selling syndicates, however, this rule may be questioned, or it is to be inferred that such subscriptions place dealers in the category of "underwriters."

It is, however, by no means clear that the Act is restricted to public marketing or offering of securities, though the "take off" point (as Berle puts it) seems at first blush to be the public offer. It is obvious that the criminal penalties under $\S I_{7}$ and civil liabilities imposed under $\S I_{2}$ have no relation to public offer. Those liabilities follow even as respects a simple, isolated transaction in no sense public.50 And apart from this excep-

49 There is some reason to believe that this device is already being developed by certain issuers.

${ }^{50}$ The language in $\S \mathrm{I} 2$ is "any person who sells." $\$ 2(3)$ in its definition of "sell" does not restrict it to public sales. 
tion the aim of the Act seems at times to be the regulation of issues however offered and at other times the control of issues publicly offered.

"Offered to the public" or "public offering" are only occasionally used. They are used to describe the amount of damages in $\$ I I(\mathrm{~g})$; securities exempt from the Act under $\S_{3}(\mathrm{a})(\mathrm{I})$; and exempt transactions under $\S_{4}(\mathrm{I})$. But though any security sold or disposed of by the issuer or bona fide offered to the public prior to July 27, I933 is exempt, nevertheless "any new offering of any such security" is not so exempt.sx Conceivably "new offering" need not be public. Purely private offerings might well suffice. Again prospectus is defined as a circular, etc. which "offers" any security for sale..$^{2}$ Here, again, the element of "public offer" is lacking. Similarly in the definition of "sell." 53 Accordingly when these words "prospectus" or "sell" are used they apply to isolated and private as well as to public offerings or sales. Thus the penalties of $\S 5$ are by no means limited in application to public issues. Similarly in the restrictions of the use of a prospectus under $\S$ Io. Nor is the liability under $\S$ II limited to issues publicly offered.54 The criterion used throughout the Act is the use of agencies of interstate commerce or of the mails, ${ }^{55}$ not public offering. And on that point the Act is in sharp contrast to the English Companies Act. ${ }^{56}$

It is at least arguable that the exigencies of the situation call for more extensive control than control over public offerings would give. ${ }^{57}$ That point need not be debated here. But it is important to note the confusion that has crept into certain parts of the Act by failing to state whether or not the principle of public offering is applicable. Other concepts (some of them even vaguer than the vague one of "public offer") have been substituted. These remain undefined. Thus an underwriter is one who acts in connection with the "distribution" of any security. "Distribution" is used again to describe non-exempt transactions of a dealer. Distribution com-

$$
{ }_{51} \S_{3}(\mathrm{a})(\mathrm{r}) . \quad \quad 52 \S 2(\mathrm{ro}) . \quad 53 \S 2(3) .
$$

54 "... any person acquiring such security . . . may ... sue." But note $\S \operatorname{rr}(\mathrm{g})$ which limits damages to the price at which the securities were "offered to the public."

${ }_{55}$ As qualified by note $\mathrm{x} 7$, sitpra.

${ }^{56} \$ 37$ of the English Act gives rights to "all persons who subscribe for any shares or debentures on the faith of the prospectus" where the "prospectus invites persons to subscribe." $\$ 380$ defines "prospectus" as "any prospectus, notice, circular, advertisement, or other invitation, offering to the public for subscription or purchase any shares or debentures of a company."

${ }^{57}$ Certain devices for circumventing the "public offer" are reported to have developed in England. In Ir6 Economist 305 (I933) it is said, "This provision does not apply to shares and debentures not offered to the public-an exception which includes the increasingly important type of issue made by 'Stock Exchange introduction,' which accounted for as much as $\sum_{15}$ 즌 millions of new capital last year. In this respect, however, the investor enjoys complete protection through the salutary stringency of the regulations laid down by the Stock Exchange Committee." 
monly carries perhaps the connotation of public offer or sale. But not necessarily so.

Again (in Schedules A and B particularly) the phrase "to be offered" is used in describing the security which must be registered. It is mostly used without any limitation as to public offer.$^{8}$ But occasionally, as in Schedule A (I6) and in Schedule B (9), data is required as to the price at which the security shall be "offered to the public."

A strict interpretation of the Act would indicate that except as restricted by the word "public" the words "offered," "distribution," "offering" etc. meant any offering or distribution. On the other hand authorities on the Act have conveyed the impression that those parts which we are now considering related to and regulated only public offerings. ${ }^{59}$ The point here is not to urge its restriction or broadening. But the Act needs amendments to clarify the ambiguity, confusion, and uncertainty attendant on its present phraseology.

If the standard of public offer were adopted, the Act would follow the English precedent. Even so ambiguities would remain; for what is a public as distinguished from a private offering? That probably would not be susceptible to statutory definition..$^{60}$ It seems of necessity a matter for definition by accretion of judicial decisions. The fact of the matter is that that problem apparently has caused no great confusion in England. ${ }^{6 \mathbf{r}}$ And

$5^{8}$ See e.g. Schedule A (ro), (I I), (r3), (I5), (r8), (2r); Schedule B (2), (3), (8), (10).

${ }^{59}$ E.g. this impression is gathered throughout H. R., 73d Cong., Ist Sess., Rep. No. 85. See particularly pp. 5, 7, 8, 9, 12, I4, I5, I6.

${ }^{60}$ There are, however, instances where "public offer" should be more clearly defined either by exceptions or otherwise. Thus $\S 4$ exempts transactions by dealers except, inter alia, transactions "within one year after the last date upon which the security was bona fide offered to the public by the issuer or by or through an underwriter." This date might be the termination of the syndicate; the date of the last advertisement by issuer, underwriter, or dealer; the last solicitation by salesmen; or if the stock was listed on an exchange that alone might constitute a public offering. If the last offering by a salesman was construed to be the last date of public offer, the rule would be unworkable. In determining a formula for ascertaining such date no fixed principle is involved. For administrative purposes, however, such provisions need clarity and definitiveness.

6r Under the Companies Act of 1908 ( $(8 \mathrm{r})$ "every prospectus issued," by or on behalf of a company had to contain certain information. And a prospectus was defined ( $\$ 285)$ as "any prospectus, notice, circular, advertisement, or other invitation, offering to the public" shares or debentures. In Nash v. Lynde, [rg29] A.C. 158 (a suit by a purchaser of shares against a director for damages for failure to include in the prospectus certain required data), the court did not pass directly on the meaning of the phrase "offering to the public" but the phrase received some discussion. Viscount Sumner said, "No particular members are prescribed. Anything from two to infinity may serve: perhaps even one, if he is intended to be the first of a series of subscribers, but makes further proceedings needless by himself subscribing the whole. The point is that the offer is such as to be open to anyone who brings his money and applies in due form, whether the prospectus was addressed to him on behalf the company or not. A private communication is not thus open ....."Id. at 169 . And Lord Buckmaster stated, "A document is not a pro- 
while it is easy to state cases that fall within the shadowland of uncertainty, the general standard is sufficiently specific as to indicate the general distinctions and to give warning of transgression. That is more than can be said for the present Act which wobbles somewhere on middle ground.

\section{RETAILING}

For his stock in trade the retail dealer has relied upon four expedients: membership in syndicates or selling groups managed by large originators or

spectus unless it is an invitation to the public, but if it satisfied the condition it is not the less a prospectus because it is issued to a defined class of the public." Id. at I7I. The case, however, turned on whether or not a prospectus had been "issued." It was held that though "issued" was not defined it would be taken to imply "some measure of publicity, however modest." As Viscount Sumner said "I do not think that the term is satisfied by a single private communication between friends, even if they are business friends. . . . . Though literally it is true that the issue is not expressly said . . . . to be an issue to the public, I think that it must be so in substance, otherwise any private letter, written by a person engaged in forming a company and advising his correspondent to take share, would become an issued prospectus if other letters were written by him asking others to do the same." $I d$. at I68-I69. And see Twycross v. Grant, [1877] 2 C. P. Div. 469 , 540. Lord Buckmaster added that "a distribution of a prospectus among a well defined class of the public would be an issue within the meaning of $\S 8 \mathrm{x}$. .... A document is not a prospectus unless it is an invitation to the public, but if it satisfied this condition it is not the less a prospectus because it is issued to a defned class of the public." $I d$. at $r 70-r 7 x$. In the case the directors had prepared a statement of the condition of the company with a proposal that certain preference shares (not then authorized) be issued to raise additional capital. This statement was circulated among the directors and to a solicitor who it was thought might be able to interest some wealthy client in the business: Through the solicitor plaintiff became interested, was employed by the company for a term and subscribed to ordinary shares of the company, not to the preference shares described in the communication.

Earlier it had been held that a prospectus marked "For private circulation only" and only circulated among 3,000 people who were shareholders in other companies in which the promoter was interested was nonetheless an offer to the public. In re South of England Natural Gas \& Petroleum Co. Ltd., [rgIr] I Ch. 573 .

But a circulation of a prospectus by a member of a syndicate to his friends was held not to be an offer "to the public" giving plaintiff-subscriber a right to recover under the Companies Act of 1900 the amount paid by him on shares, the claim being that since there had been a public offering and the minimum subscription had not been obtained plaintiff had a statutory right to the return of his payment. Mr. Justice Warrington said that an offer to the public meant an offer of shares to anyone who should choose to come in. Sherwell v. Combined Incandescent Mantles Syndicate Itd., 23 T.I. Rep. 482 (I907). The court also interpreted the statute giving the right to rescission to mean a public offer by the company not by some individual without authority from the company. Accord: Sleigh v. Glasgow \& Transvaal Options Itd., 6 Sess. Cas. 420 (I9O4) (circulation of a document by promoters' directors to friends, case arising under Companies Act of I 900 in action against company to have plaintiff's name removed from register of shares. "Prospectus" was defined in the Act as it is presently defined in the Act of 1929).

Interpretations of "public offering" under Blue Sky Laws are of some utility. Gillespie v. Long, 212 Ala. 34, Ior So. 65I (I924).

More remote analogies arise in construction of "agencies for public use" under public utility statutes. See e.g. Terminal Taxicab Co. Inc. v. District of Columbia, 24I U.S. 252, 36 Sup. Ct. . 583 (1915); Anderson v. Fidelity \& Casualty Co., 228 N.Y. 475, $x 27$ N.E. 584 (I920). 
the principal underwriters of issues; purchases from, or sales against, the commitments of such members either at a "dealer's concession"6z allowed under syndicate or selling group agreements or on an "investment guaranteed" basis in contravention of most such agreements; ${ }^{63}$ selling against other inventory of other dealers at some agreed-upon discount; its own trading department's purchases in advance of or to fill cústomer orders for a trading profit; commission sales, usually without commitment, for issuers or affiliates of issuers; and their own originations. The importance of these various sources of inventory has varied with the times. ${ }^{64}$ Except for a few large retailing organizations and the retail departments of originating houses, their own originating is not an important source. Trading is the resource of the house without syndicate affiliation, the means of providing a diversified inventory to meet the various requirements of customers, and the method of providing inventory when other sources are unproductive. Dealer commissions or reallowances are too small (typically $\frac{1}{4}$ of $1 \%$ ) to be profitable, and "investment guaranteed" selling is unimportant in the aggregate.

The retail business has been largely dependent, therefore, upon the large originating houses and to some extent directly upon issuers (or the security affiliates of issuers $)^{65}$ for its securities. Wholesaling methods in the majority of instances employed some form of underwriting by the retailer, so that risks of sale were further spread from the much smaller group of original or intermediate underwriters over the whole group, usually some hundreds, of retailers. It was the aim of the originating underwriter to accomplish this wide distribution of risk as nearly as possible simultaneously with his own acceptance of a commitment. The underwriting provided by retail dealers was thus both real and an incentive for them to sell. Selling groups in which retailers promptly subscribed for the amounts offered them constituted as effective a method of risk spreading

${ }^{62}$ Not to be confused with the "usual and customary distributors' or sellers' commission" of $\S 2$ (FI), though it would probably be included in that definition.

${ }_{3}$ Cf. Galston, Security Syndicate Operations (rev. ed., x928), New York: Ronald Press, pp. 55 and I20-1 22. Also, Bates \& Douglas, op. cil., supra, note 15, 4x Yale L. Jour. 949, 95X (r932).

${ }^{64}$ Unlike most other merchants the security retailer obviously cannot depend upon a continuous or stable volume of new inventory being supplied him.

6s While never of primary importance, yet at times and for some classes of retail houses, the original or secondary distribution (cf. Bates \& Douglas, op. cit., supra, note I5, 4I Yale L. Jour. 949. 952 (1932) of certain investment trust and utility holding company stocks for the issuer (or an affiliate) has proved a not inconsiderable source of revenue, especially since dealers were seldom required in those cases to bear any of the risk of sale, but only to sell for a commission. which might, however, be contingent upon investment placement for a stipulated period. 
as the selling syndicates. Those in which subscriptions were made only against firm orders from customers, however, left the risk of sale upon the "underwriters."

Retail selling commissions naturally varied with market conditions, the kinds of securities, and the nature of the commitments taken, so that it is difficult to name any normal or average commission, except in the light of those factors. Most of them, however, would have fallen in a range of from $x \%$ to $3 \frac{1}{2} \%$. In the case of selling syndicates the additional gross spread for underwriting (against which expenses and losses were chargeable) would usually have amounted to from $\frac{1}{2}$ of $1 \%$ to $1 \frac{1}{2} \%$. Taking the total gross spread for a selling syndicate at from $2 \frac{1}{2} \%$ to $4 \frac{1}{2} \%$, some estimate of the economy achieved in distributing expense may be gained by comparable retailing spreads for other commodities and services. One comparison might be with automobiles selling at retail for about $\$ 2,000$ (somewhere in the neighborhood of the unit of sale for securities), where the average retail spread would probably be from 3 to 7 times that for securities.

It has been noted in a preceding section how it would be wholly possible to make dealers and brokers "underwriters" under the Act. Selling syndicate participation would probably place a retail dealer in this category. Whether a selling group member would be so classed is less clear. Subscription by a dealer for securities on selling group terms in advance of firm orders from customers might take him out of the exemption in $\S 2$ (II). ${ }^{66}$ The same effect might follow from any provision in the selling agreement requiring him to repurchase securities originally sold by him which came back upon the market during a specified period. ${ }^{67}$

Assuming, however, that they are not "underwriters" under the Act, they are nevertheless subjected to considerable regulation. Dealers are defined so as to include brokers. ${ }^{68}$ But brokers are given some exemptions

${ }^{66} \S_{4}(\mathrm{I})$, however, apparently differentiates "dealers" from "underwriters" and with reference to the former excepts from exemption "transaction as to securities constituting the whole or a part of an unsold allotment to or subscription by such dealer as a participant in the distribution of such securities," with the seeming inference that participation and commitment for securities does not make such a dealer an "underwriter."

${ }^{67}$ Query, however, whether the contingency of his commission upon investment placement, could be held to have that effect.

$68 \S 2$ (I2). But the definition is even broader than what are normally described as security merchants and security brokers. It includes "any person who engages either for all or part of his time, directly or indirectly, as agent, broker or principal, in the business of offering, buying, selling, or otherwise dealing or trading in securities by another person." Accordingly it is broad enough to include individual investors, investment trusts, banks, insurance companies, etc. A happier way of accomplishing the legislative intent would have been to limit it to persons engaged directly or indirectly in the "business of distributing securities at wholesale or retail." 
not shared by other "dealers." For example, unless a security is registered it is in two circumstances unlawful for a "dealer" to make use of any means of interstate commerce or of the mails to "sell or offer to buy" the security or to deliver the security for sale or after sale. It is likewise unlawful to transmit a prospectus unless the prospectus meets with the requirements of the Act or to deliver the security unless accompanied or preceded by a proper prospectus. Violation of these provisions subjects the "dealer" to criminal liability, ${ }^{69}$ and also subjects him to civil liability under $\S$ I 2 giving the person who purchases from him a right of rescission or damages ipso facto. The first of these circumstances is a transaction by the "dealer" within a year after the last date upon which the security was bona fide offered to the public..$^{70}$ The vagueness of the rule has been commented upon above. The other instance is the distribution by the dealer of the whole or a part of an unsold allotment to or subscription by the dealer as a participant in the distribution of such securities by the issuer or underwriter. ${ }^{7 x}$ So as respects new issues of securities the "dealer" must be in a position within a year after the last date of the public offer to have the security registered and to have available in all his transactions as "dealer" sufficient prospectuses to satisfy the requirements of $\S 5$. And in case he has taken a commitment under a selling group (and even though he is not an underwriter), he is restricted in a similar way but to a greater extent since there is no time limitation of a year or any other period when his duty to conform to $\S 5$ would terminate.

Two illustrations of possible hardships on dealers may be given. As has been noted securities issued in the process of a bona fide reorganization "under the supervision of any court" need not be registered for the purposes of such issuance. ${ }^{72}$ Nevertheless for one year after their issuance (assuming the issuance to amount to a public offering) dealers' transactions in these securities would violate the Act unless the securities were registered. No machinery is set up whereby a registration can be obtained. And in view of the severity of the penalties on registration statements it is doubtful if registration statements would be made unless necessary. Dealers may through their trading departments unwarily get trapped with such inventory and have their hands tied for a year.

Additional complications of a similar kind arise in case of the buying and selling of securities after the expiration of thirteen months from the effective date of the registration statement. A prospectus where so used

$69 \$ 24$. Note also possible liability under $\$$ I 7 discussed, supra, note 18 .

70 "by the issuer or by or through an underwriter." $\$ 4(\mathrm{r})$. ${ }^{75} \S_{4}(\mathrm{r})$.

${ }^{72} \$ 4(3)$. It is by no means clear that this is not a "public" offer and therefore that the transaction by the dealer is exempt under $\$ 4(\mathrm{I})$. 
must contain information not more than twelve months old. ${ }^{73}$ The Act gives no dealer the power to obtain a freshly dated prospectus. There might well be reluctance on the part of the issuer to supply it, because of the additional uncompensated risk involved. So far then as the dealer market goes fluidity of certain securities at certain times may be greatly curtailed.

If, however, the "dealer" (as defined in the Act) merely acts as broker, ${ }^{74}$ he is exempt from such regulation except as indicated hereafter. The security need not be registered and no prospectus need be furnished or sent even though agencies of interstate commerce or the mails are used. But if the broker solicits orders he is liable in the same fashion as other "dealers." 75 Solicitation is not defined. Litigation on this point under Blue Sky Laws has been great. Certainly the line between solicitation and mere acceptance of orders is (and perhaps must remain) vague. The point at which the draftsmen are aiming seems clear. When the pressure for distribution begins to be applied the parties applying it are placed under a duty to furnish the investor with information respecting the security which the Act deems pertinent. Upon "dealers," however, they may have placed restrictions not necessary to this purpose, because applied as well to mere sale without sales effort.

But the Act has even more far reaching effects on the retailing of securities..As noted, "dealers" (including brokers) may be liable civilly un$\operatorname{der} \S \mathrm{I} 2$ (and criminally) if $\S 5$ is violated. They may also be liable under $\S$ I2 though the security purchased or sold is exempt from other provisions of the Act. Thus a dealer (in the strict sense) "sells" a railroad bond which need not be registered ${ }^{76}$ by the use of an agency of interstate commerce or of the mails. If the "prospectus or oral communication" includes an untrue statement of a material fact or omits to state a material fact necessary in order to make the statements not misleading (the purchaser not knowing of such untruth or omission) and the dealer does not prove that he did not know and in the exercise of reasonable care could not have known of the untruth or omission, he is liable to the purchaser from him either for damages or rescission. This civil penalty is applicable not only to dealers but to "any person" who "sells" a security, with the possible exception of brokers discussed hereafter. The result will be in the direction of the dealer supplying full information or giving no information except the name of the security and its price. Intermediate declarations by the dealer become hazardous. Market letters by dealers become risky. Oral advice becomes dangerous if related to an interstate transaction.

As to brokers the liability under $\S \mathrm{I2}(2)$ is at best ambiguous. If a broker "sells" he is liable to the person "purchasing" from him. A strict bro-
${ }^{73} \S \mathrm{ro}(\mathrm{b})(\mathrm{r})$.
${ }_{74} \S_{4}(2)$.
$75 \S 4(2)$.
$7^{6} \S 3$ (a) (6). 
ker was held as a matter of common law not to sell. The person who purchased got title through, not from, him. ${ }^{77}$ Yet "sell" is defined in the Act so broadly as to include a broker's activities. ${ }^{78} \mathrm{He}$ certainly is making a "disposition of" the security; or an "attempt or offer to dispose of" the security; or a "solicitation of an offer to buy." "Purchase" is not defined. But if it is taken to mean the correlative of "sell" as defined in the Act the broker assumes a liability under $\S$ I2(2). It would seem at first blush that it was not the sense of the Act to embrace brokers at this point. But it could well be argued that brokers were intended for inclusion. They are not exempt from $\S 5$ if they solicit orders. Brokers' market letters may well be construed as soliciting orders. ${ }^{79}$ If they make any such statement about a security they run the danger of being afoul of $\S 5$. Since statements amounting to solicitation bring them in under $\S$ I2(I) perhaps statements inaccurately describing the security bring them in under $\$ \mathrm{I2}(2)$. At least the Act needs clarification on this point.

\section{CONCLUSION}

The Act has been in effect for too brief a period during which too many other factors of major consequence have been operative to permit proof of its incidence in many particular respects. The relative parts played by market conditions, by the unwillingness of issuers and their officers to assume the new obligations of the Act, by unwillingness of issuers and bankers to operate in the face of risks arising solely from the ambiguity in the Act, and by the hesitancy of banking houses of substance to incur the new risks are matters of estimate rather than informed judgment.

Nor, as pointed out at the beginning of this essay, is it possible to predict with any degree of accuracy what the future course will be. ${ }^{80}$ In terms merely of increased business and legal risks, however, a few rather general conclusions have been drawn. It may be that underwriting as it has been performed in this country will practically disappear. Or fewer substantial houses may underwrite, with a consequent effect upon the size and kinds of issues and the relative abilities of various issuers to obtain capital. Or, again, a host of impecunious persons (not necessarily strawmen) may appear and take over, perhaps the name but not the function of, origination and underwriting. Or, with or without clarifying amend-

7 See note 16, supra.

${ }^{8}$ It is possible, though not likely, that the section woyld also cover the case of a broker not "selling" for himself or his principal.

79 The effectiveness of a "hedge" clause to the effect that the letter is "not to be construed as a solicitation of orders" for the security described may be questioned.

${ }^{80}$ Certain predictions of effects have been made by Dean, The Federal Securities Act: I, 8 Fortune 5o (1933). 
ments to the Act, substantial houses may contrive to do business as in the past (if securities are available to them from prospective issuers), for it should be remembered that theirs is a fraternity not unused to accepting risks subject to no mathematical bases of appraisal. On the other hand, the attitude of issuers and their officers and directors toward the new risks may be largely controlling. Thus if the Act is as revolutionary as some think, the raising of capital will be seriously hindered and the methods employed will take quite different forms. In such processes investment bankers as they are known today may have little or no place.

Viewed broadly as a function, however, investment banking will still be performed, though possibly wholly or in part by other institutions. Those might be the issuers, governmental agencies, ${ }^{8 x}$ or financial institutions other than "investment bankers." The Act presupposes no such shift. But if its direct or indirect effect is such an induced transference it is perhaps time to consider the larger issue on its merits. Such an effect, of course, is no necessary corollary to providing investors with the "truth about securities"-a purpose needing no consideration except as to the means of its accomplishment.

Meanwhile a major problem is the elimination from the Act of its ambiguities and inconsistencies. In that connection it should be said with Felix Frankfurter that: "Like all such legislative beginnings, the Act must be deemed definitive merely in principle and not in detail." 82 Insofar as there are ambiguities and inconsistencies in the Act it should be promptly amended. To await an accretion of judicial decisions to clarify these ambiguities seems undesirable. Those decisions, especially since they will be coming from the courts of all the states and territories as well as from the federal system, will be slow to acquire even a semblance of uniformity. The interim will be beneficial to no one except the legal profession. Incidental effects may be the paralyzing of legitimate activity. If there are any standard specifications for legislation they are clarity and consistency. Risks are significant to business. The ability to predict those risks and to conform to the spirit and design of the legislation is of great moment, though it is never possible in all cases no matter the degree of clarity in the law. There will always remain room for play by the courts in adapting legislation to new and changing conditions and in permitting the experiment to evolve against the urge for strict and technical construction. But that growth calls for clear expression of principle and consistent and unambiguous treatment of detail.

${ }^{8 x}$ In this connection see the challenging consideration of the possible rôle of the Reconstruction Finance Corporation by Berle in High Finance: Master or Servant, 23 Yale Review 20 (1933).

${ }^{82}$ The Federal Securities Act: II, 8 Fortune 50, I09 (I933). 